\title{
Effects of Solidification Rate and Settling Time of SiC Particles on the Macrosegregation of Carbon in Silicon Ingots
}

\author{
TIAGO R. RIBEIRO, JOÃO B. FERREIRA NETO, \\ and MARCELO A. MARTORANO
}

\begin{abstract}
The macrosegregation of carbon in silicon was studied aiming for silicon refining for photovoltaic applications. Experiments of directional solidification upward and of settling of $\mathrm{SiC}$ particles in the melt were carried out in a Bridgman furnace using electronic grade silicon intentionally contaminated with carbon. Mold pulling velocities in the range between 5 and $80 \mu \mathrm{m} / \mathrm{s}$ and settling time periods of 1 and 6 hours were adopted in the experiments. In the resulting cylindrical ingots, the macrosegregation of carbon along the axial direction was measured and their macro and microstructures revealed and examined. In all directional solidification experiments, the carbon concentration increases to the ingot top as result of an accumulation of $\mathrm{SiC}$ particles in this region. For the lower velocities $(<40 \mu \mathrm{m} / \mathrm{s})$, a larger particle accumulation and columnar grains aligned axially and pointing to the ingot top are seen, which is consistent with the pushing of $\mathrm{SiC}$ particles by a planar solid-liquid interface. For the settling experiments, the carbon concentration increases from the ingot top to the bottom as a result of the accumulation of $\mathrm{SiC}$ particles at the bottom. This accumulation is probably caused by the settling of $\mathrm{SiC}$ particles, but an increase in the settling time from 1 to 6 hours have no significant effect in the macrosegregation profile. Finally, in the conditions of the present experiments, the directional solidification of silicon at mold pulling velocities lower than $40 \mu \mathrm{m} / \mathrm{s}$ is more effective to remove carbon from silicon than the settling of $\mathrm{SiC}$ particles during times up to 6 hours.
\end{abstract}

DOI: $10.1007 / \mathrm{s} 40553-014-0028-3$

(C) ASM International (ASM) and The Minerals, Metals, \& Materials Society (TMS) 2014

\section{INTRODUCTION}

IN the past decade, the photovoltaic energy has become an alternative to traditional nonrenewable fossil energy sources. Silicon with maximum impurity content of $\sim 1$ ppmw is the most used material for solar cell manufacturing. This is the so-called solar grade silicon (SoGSi), which can be produced by refining the less pure metallurgical grade silicon (MGSi). The growing demand for SoGSi gave rise to alternative production routes based on metallurgical operations. The main objective of these operations is the removal from MGSi of metallic impurities, such as, $\mathrm{Fe}, \mathrm{Al}$, and $\mathrm{Ti}$, and of $\mathrm{P}, \mathrm{B}$, and $\mathrm{C}$.

The typical concentration of carbon in MGSi is about 500 ppmw, present in a solution with solid/liquid silicon and as silicon carbide ( $\mathrm{SiC}$ ) particles embedded in this solution. The carbon solubility in liquid silicon has been determined by different authors, but the values differ in one order of magnitude, as shown by Dalaker and

TIAGO R. RIBEIRO, Assistant Researcher, and JOÃO B. FERREIRA NETO, Researcher, are with the Laboratory of Metallurgical Processes, Institute for Technological Research of São Paulo State, Av. Prof. Almeida Prado, 532, São Paulo, SP 05508-901, Brazil. Contact e-mail: tiagorr@ipt.br MARCELO A. MARTORANO, Associate Professor, is with the Department of Metallurgical and Materials Engineering, University of São Paulo, Av. Prof. Mello Moraes, 2463, São Paulo, SP 05508-900, Brazil.

Manuscript submitted February 5, 2014.

Article published online September 9, 2014
Tangstad. ${ }^{[1]}$ These authors claim that the spread in the solubility values is a result of uncontrolled sources of carbon and oxygen, such as the crucible wall. Therefore, Dalaker and Tangstad ${ }^{[1]}$ carried out carefully controlled experiments and obtained the carbon solubility in liquid silicon as $65 \mathrm{ppmw}$ at the melting point $1687 \mathrm{~K}$ $\left(1414{ }^{\circ} \mathrm{C}\right)$. Therefore, approximately $90 \mathrm{pct}$ of carbon in MGSi is combined in $\mathrm{SiC}$ particles. These particles have two deleterious effects for photovoltaic applications: wire breakage during silicon wafering ${ }^{[2]}$ and shunting in solar cells. ${ }^{[3]}$ To avoid these problems, the SEMI PV17-0611 ${ }^{[4]}$ standard sets a maximum concentration limit of 43 ppmw (100 ppma) of carbon in the SoGSi produced by the metallurgical route.

Directional solidification and settling of $\mathrm{SiC}$ particles have been reported in the literature to remove carbon from silicon. In general, when particles interact with an advancing solidification front, they can be pushed or engulfed, depending on the critical front velocity for pushing/engulfment transition (PET). At relatively low solidification front velocities, particles of $\mathrm{SiC}$ can be pushed ahead and, during directional solidification upward, be transported to the ingot top..$^{[5,6]}$ On the other hand, if silicon remains in the liquid state for a period of time, $\mathrm{SiC}$ particles settle down and accumulate at the ingot bottom. ${ }^{[7,8]}$ In both cases, carbon macrosegregation occurs and leads to the elimination (refining) of carbon from some parts of the ingots. The objective of the present work is to study the effects of the pulling velocity of the mold of a Bridgeman furnace and of the 
time for settling of $\mathrm{SiC}$ particles on the macrosegregation of carbon in silicon. The consequences of this macrosegregation on the elimination of carbon from the silicon ingots to produce SoGSi are discussed.

\section{DESCRIPTION OF EXPERIMENTS}

Experiments of settling and directional solidification upward were both carried out in a Bridgman furnace. Electronic grade silicon (EGSi), with maximum total impurity concentration of $\sim 1 \mathrm{ppbw}$, was first melted in a graphite crucible heated in a plasma furnace to intentionally contaminate the silicon with carbon at the concentration of $1200 \pm 300$ ppmw. This carbon-contaminated EGSi was then re-melted in a Bridgman furnace inside a 30-mm-diameter cylindrical quartz mold internally coated with silicon nitride. The furnace was heated by an induction coil at a rate of $14.5^{\circ} \mathrm{C} / \mathrm{min}$ up to $1773 \mathrm{~K}\left(1500{ }^{\circ} \mathrm{C}\right)$, evacuated to the pressure of $10 \mathrm{~Pa}$, and finally pressurized with argon to $70 \mathrm{kPa}$. At $1773 \mathrm{~K}\left(1500{ }^{\circ} \mathrm{C}\right)$, the mold was held in the furnace hot zone during 20 minutes for temperature stabilization.

In the directional solidification experiments, after stabilization, the mold was pulled from the furnace hot zone down into the cold zone at different velocities, namely, 5, 10, 20, 40, and $80 \mu \mathrm{m} / \mathrm{s}$. An additional experiment was conducted in which the mold was rapidly pulled $(>3000 \mu \mathrm{m} / \mathrm{s})$ to the cold zone in order to enforce rapid solidification and maintain the initial size and position of particles in the solidified ingot. Therefore, the initial condition of the melt for all experiments would be revealed in this special experiment. In the settling experiments, after temperature stabilization, the mold was held in the furnace hot zone for either one or six hours to allow some settling of the $\mathrm{SiC}$ particles present in the melt. After this settling period, the mold was rapidly pulled to the furnace cold zone to prevent the solidification front from pushing the particles, disturbing their final distribution.

After solidification and cooling to room temperature, the 30-mm-diameter, 100-mm-height cylindrical ingots were sectioned longitudinally for macro and microstructure examination. The macrostructures were revealed by grinding and etching the longitudinal section in an aqueous solution of $33 \mathrm{wt}$ pet $\mathrm{NaOH}$ at $373 \mathrm{~K}\left(100{ }^{\circ} \mathrm{C}\right)$ during 3 minutes. To observe the microstructures in the optical microscope, the sections were ground, polished, but not etched. Samples were also extracted at different distances from the ingot base, along the ingot axis, for chemical analysis of carbon in a LECO CS-300 system.

\section{CARBON MACROSEGREGATION, MACRO AND MICROSTRUCTURES}

The carbon concentration profiles for the ingots obtained in the directional solidification and settling experiments are shown in Figures 1 and 2, respectively, as a function of the relative distance to the ingot base, $\mathrm{h} / \mathrm{H}$, where $\mathrm{h}$ is the absolute distance and $\mathrm{H}$ is the ingot

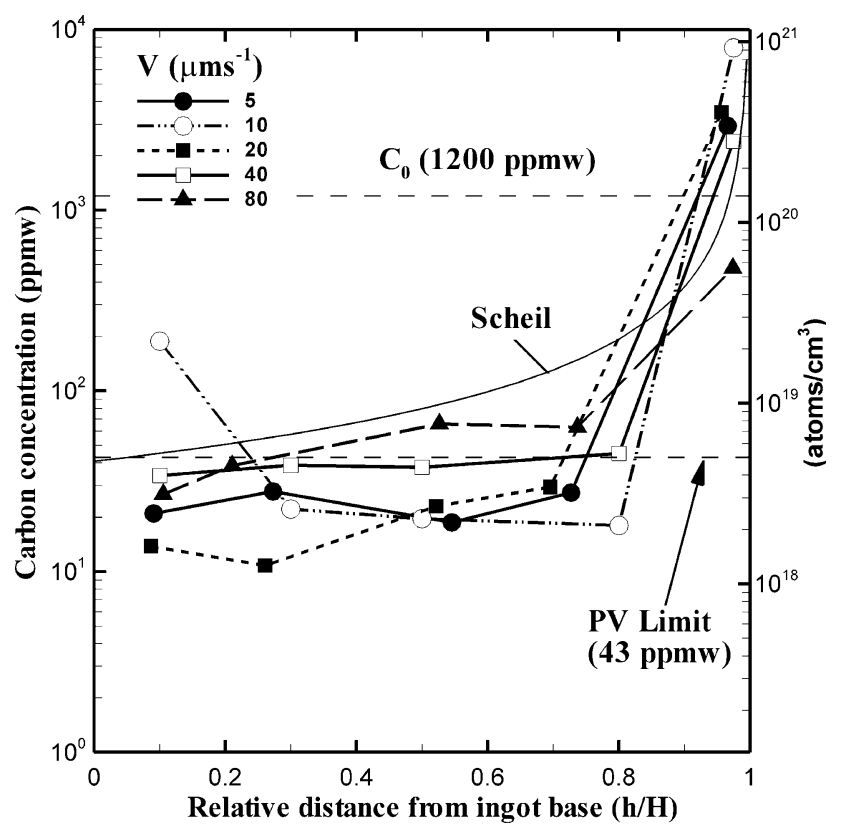

Fig. 1-Macrosegregation profiles of the ingots obtained in the directional solidification experiments for different mold velocities $(V)$ : carbon concentration as a function of the relative distance $(h /$ $H$ ), where $h$ is the distance from the ingot base along the axial direction and $H$ is the ingot length. The concentration profile given by the Scheil equation, the initial carbon concentration $\left(C_{0}\right)$, and the maximum limit for carbon content according to the SEMI PV 17-0611 are also presented.

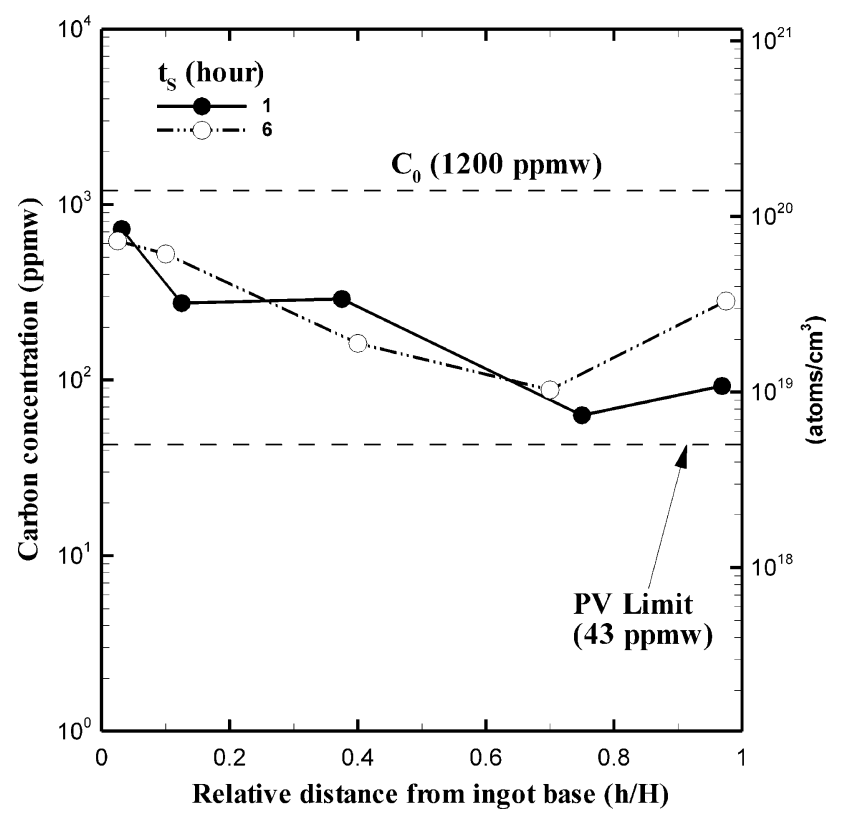

Fig. 2-Macrosegregation profiles of the ingots obtained in the settling experiments for different settling times $\left(t_{\mathrm{s}}\right)$ : carbon concentration as a function of the relative distance $(h / H)$, where $\mathrm{h}$ is the distance from the ingot base along the axial direction and $H$ is the ingot length. The initial carbon concentration $\left(C_{0}\right)$ and the maximum limit for carbon content according to the SEMI PV 17-0611 are also presented.

length. The corresponding macrostructures of the ingots are given in Figures 3 and 4. Typical microstructures observed in these ingots at different distances from the 


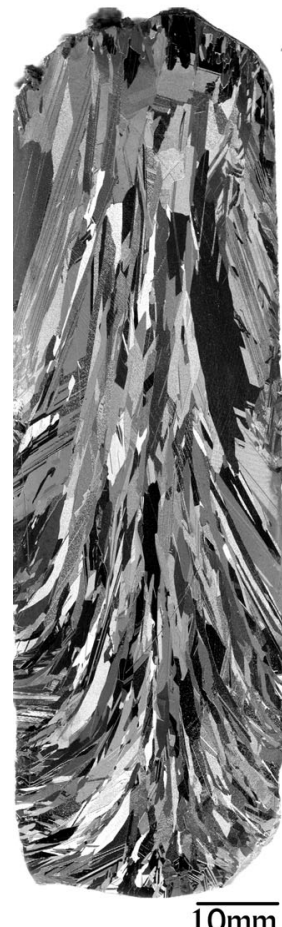

(a)

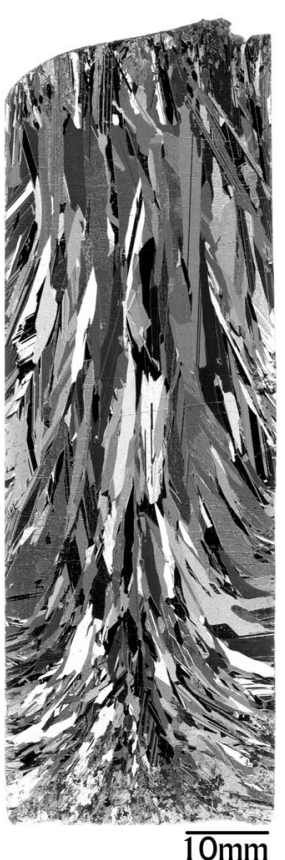

(b)

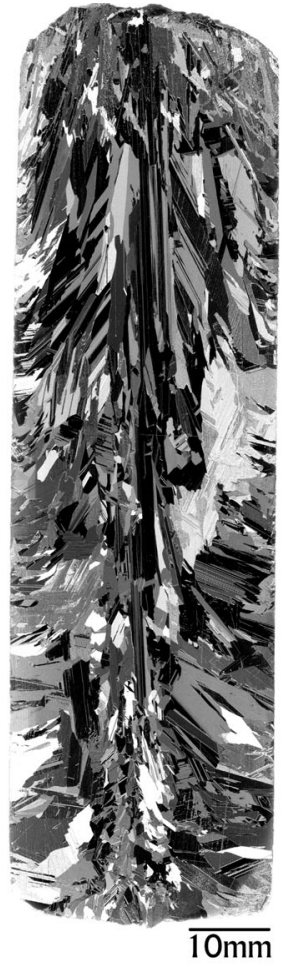

(c)

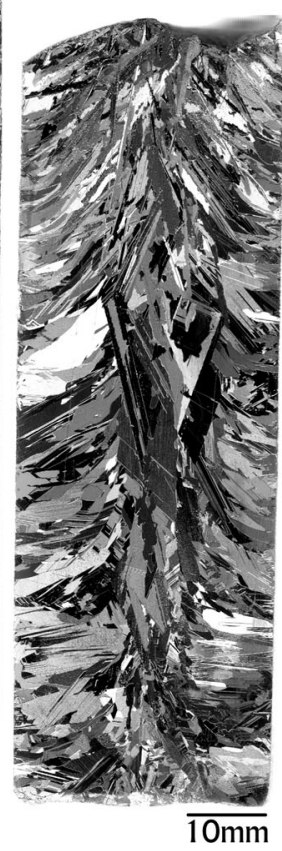

(d)

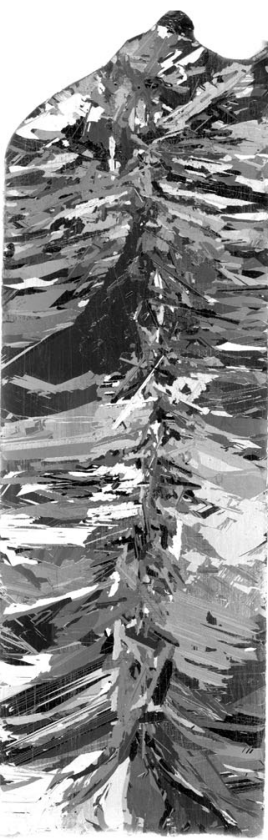

(e)

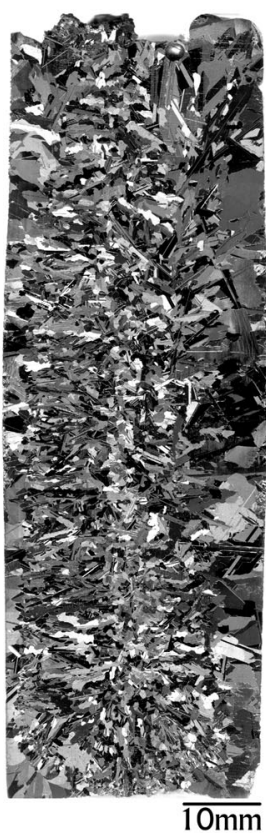

(f)

Fig. 3-Macrostructures of the ingots obtained in the directional solidification experiments at different mold velocities: $(a) 5 \mu \mathrm{m} / \mathrm{s} ;(b) 10 \mu \mathrm{m} / \mathrm{s}$; (c) $20 \mu \mathrm{m} / \mathrm{s} ;($ d) $40 \mu \mathrm{m} / \mathrm{s} ;($ e) $80 \mu \mathrm{m} / \mathrm{s} ;(f)>3000 \mu \mathrm{m} / \mathrm{s}$.

base are also presented in Figures 5 and 6. These experimental results are discussed in the next sections.

\section{EFFECTS OF MOLD PULLING VELOCITY ON THE GRAIN MACROSTRUCTURES}

For the mold pulling velocities of 5 and $10 \mu \mathrm{m} / \mathrm{s}$ (Figures 3(a) and (b)), both ingots show a macrostructure of grains elongated and aligned in the axial direction. Some grains nucleated at the lateral wall of the mold and grew to the center, eventually bending upward, especially in the lower parts of the ingots. For $20 \mu \mathrm{m} / \mathrm{s}$ (Figure 3(c)), the macrostructure displays two different structures. The first, which extends up to $70 \mathrm{~mm}$ from the base, consists of grains that nucleated at the lateral walls and grew radially, combined with axially aligned elongated grains at the center. Above $70 \mathrm{~mm}$ from the base, the grain structure is similar to that of the experiments carried out at 5 and $10 \mu \mathrm{m} / \mathrm{s}$, showing grains growing from the wall and bending upward. As velocity increases to $40 \mu \mathrm{m} / \mathrm{s}$ (Figure 3(d)), the whole grain structure is similar to that observed at the lower part of the ingot solidified at $20 \mu \mathrm{m} / \mathrm{s}$. Finally, when the mold velocity further increases to $80 \mu \mathrm{m} / \mathrm{s}$ (Figure 3(e)), the central region of axially aligned grains virtually disappears and the radially aligned columnar grains extend approximately throughout the ingot section. For the experiment of rapid mold pulling $(V>3000 \mu \mathrm{m} / \mathrm{s})$, the ingot macrostructure given in Figure 3(f) displays grains that are predominantly equiaxed with a narrow region of colum- nar grains aligned in the radial directions, close to the lateral mold wall.

When the mold is pulled from the furnace hot zone at a sufficiently large velocity, the mold lateral wall is completely exposed to the furnace cold zone before solidification begins, resulting in an intense radial heat extraction flux that causes the formation of columnar grains in the radial direction, as observed near the wall in Figure 3(f) for $V>3000 \mu \mathrm{m} / \mathrm{s}$. It is also clear in this macrostructure that the columnar front was later blocked by equiaxed grains growing ahead of this front, resulting in an equiaxed-to-columnar transition (CET). When the mold pulling velocity decreases to $80 \mu \mathrm{m} / \mathrm{s}$, the lateral wall is exposed to the cold zone more slowly, decreasing the radial heat flux and causing the formation of columnar grains extending almost to the ingot center, where very few small equiaxed grains are still observed (Figure 3(e)). The macrostructure indicates that the lower heat extraction decreased the growth velocity of the columnar front, also decreasing the undercooling at this front and preventing nucleation of new grains ahead of the front, as explained by Hunt. ${ }^{[9]}$

When the mold pulling velocity is further decreased, the lateral wall of the lower part of the mold is exposed to the cold-zone before the upper part and remains in this position for a relatively long time due the low mold velocity. Therefore, a significant amount of heat is transferred from the upper liquid to the underlying solid and finally to the cold zone of the furnace, rather than being transferred radially and directly through the lateral walls. In this case, the heat flux is mainly axial in the 


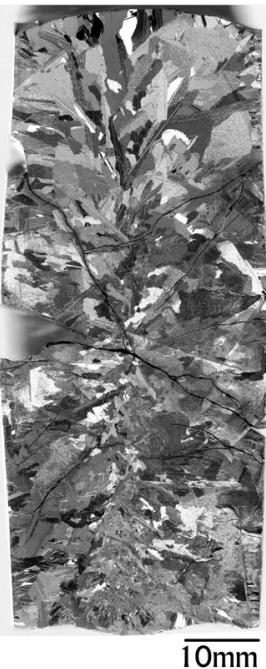

(a)

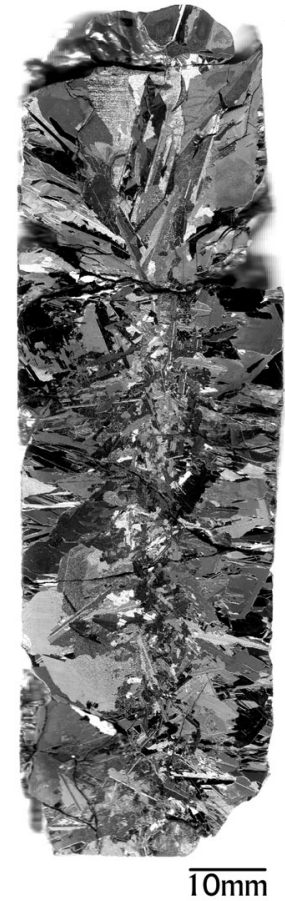

(b)
Fig. 4-Macrostructures of the ingots obtained in the settling experiments during different settling periods: $(a) 1 \mathrm{~h}$; (b) $6 \mathrm{~h}$.

middle and upper parts of the ingot, resulting in columnar grains aligned in the axial direction, as observed in the ingot macrostructures given in Figures 3(a) and (b) for mold velocities 5 and $10 \mu \mathrm{m} / \mathrm{s}$, respectively. The macrostructures for the mold velocities 20 and $40 \mu \mathrm{m} / \mathrm{s}$, illustrated, respectively, in Figures 3(c) and (d), represent a transition between those for 80 and $10 \mu \mathrm{m} / \mathrm{s}$, as expected from a continuous macrostructure variation caused by a gradual increase in the heat extraction.

\section{EFFECTS OF MOLD PULLING VELOCITY ON CARBON MACROSEGREGATION}

In the ingots obtained in the directional solidification experiments, carbon concentration increases from the ingot bottom to the top regardless of the mold pulling velocity (Figure 1). The concentration at the top of the ingots for velocities between 5 and $40 \mu \mathrm{m} / \mathrm{s}$ is nearly one order of magnitude larger than that for $80 \mu \mathrm{m} / \mathrm{s}$, displaying a more intense carbon macrosegregation. Moreover, for these lower velocities ( $V \leq 40 \mu \mathrm{m} / \mathrm{s}$ ), the carbon content in the refined region $(h / H \tilde{<} 0.8)$ is lower than the maximum limit recommended by the SEMI PV17-0611. ${ }^{[4]}$ An abnormal high concentration, however, was observed near the ingot base for the experiment carried out at $10 \mu \mathrm{m} / \mathrm{s}$. This was due to the presence of unusually large particles at the bottom of the ingot (Figure 5(c)). The origin of such particles was not investigated, but they may have formed during the intentional carbon contamination in the plasma furnace.

To investigate the mechanism responsible for the formation of the concentration profiles in Figure 1, a profile calculated by the Scheil equation ${ }^{[10]}$ is included. In this calculation, the relative distance from the ingot base was adopted as the solid fraction, the average carbon concentration was assumed as 1200 ppmw, and a solute partition coefficient of 0.034 , which is one of the lowest values reported in the literature ${ }^{[11]}$ was considered. The discrepancy between the measured and calculated profiles is evident. If a larger partition coefficient reported in the literature were used in the calculations, the Scheil profile would shift upward, increasing the discrepancy. To derive the Scheil equation, the solute transport in the liquid is assumed sufficiently rapid to homogenize its composition. When a more slowly mass transport is assumed, the concentrations at lower relative distances $(h / H)$ would increase and also shift the profile upward ${ }^{[12]}$ increasing the discrepancy. Therefore, it seems possible to conclude that the measured concentration profiles were not caused by simple carbon rejection by the solid into the liquid at a planar solidliquid interface during the upward solidification. The pushing of $\mathrm{SiC}$ particles by the solid-liquid interface, which might be the most important mechanism determining the present carbon concentration profiles, is examined next in relation to the macro and microstructures of the ingots.

To reveal the initial distribution of $\mathrm{SiC}$ particles in the silicon melt at the beginning of all experiments, discarding the possibility of an accumulation of particles due to either directional solidification or particle settling, the mold was pulled at a velocity larger than $3000 \mu \mathrm{m} / \mathrm{s}$ right after melting and temperature stabilization. This procedure would enforce relatively large solidification velocities in the radial direction, as explained in Section IV, originating a nonplanar solid-liquid interface, which is confirmed by the equiaxed grain structure given in Figure 3(f). These conditions would prevent pushing of $\mathrm{SiC}$ particles during solidification, preserving their initial configuration in the melt. The distribution of $\mathrm{SiC}$ particles in the ingot from this special experiment was observed to be uniform throughout the whole ingot volume, indicating that any accumulation seen in the final ingots must have occurred later, after the beginning of the experiments. An example of the configuration of particles at the ingot bottom is shown in Figure 5(g). At the ingot top, however, an enriched layer of particles was also observed, as shown in Figure 5(h). This layer seems to have formed as a result of the flow of the melt containing $\mathrm{SiC}$ particles from the central liquid to the ingot top (exudation), near the end of solidification, driven by the expansion experienced by silicon during solidification.

The initial particle distribution in the melt was uniform. Therefore, the accumulation of $\mathrm{SiC}$ particles at the ingot top can only have occurred during the solidification experiments. For the lowest mold velocities, namely 5,10 , and $20 \mu \mathrm{m} / \mathrm{s}$, a planar solid-liquid interface is expected, as described by Martorano et al. ${ }^{[12,13]}$ The structure of columnar grains aligned in the axial direction observed for these velocities (Figures 3(a) through (c)) is consistent with a planar solid-liquid interface growing upward, pushing the $\mathrm{SiC}$ particles to the ingot top and causing the larger carbon 


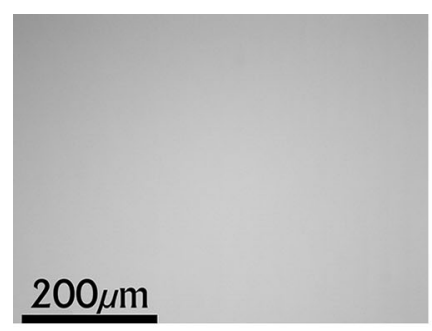

(a)

$5 \mu \mathrm{m} / \mathrm{s}$

$5 \mathrm{~mm}$

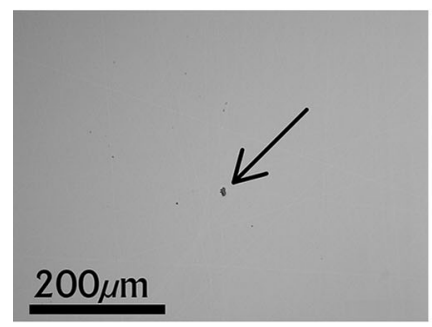

(e)

$40 \mu \mathrm{m} / \mathrm{s}$

$5 \mathrm{~mm}$

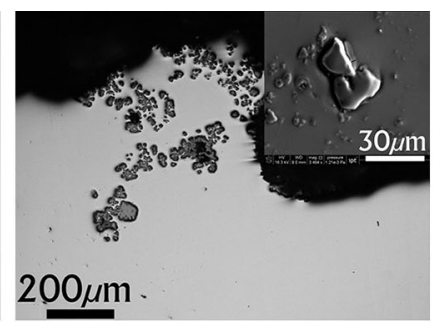

(b)

$5 \mu \mathrm{m} / \mathrm{s}$

$110 \mathrm{~mm}$ - top

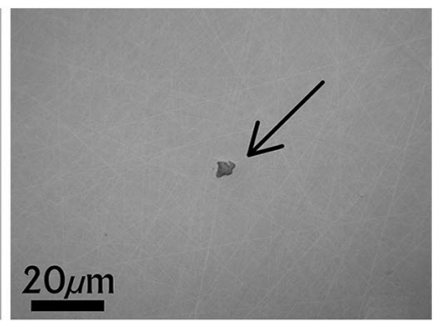

(f)

$80 \mu \mathrm{m} / \mathrm{s}$

$5 \mathrm{~mm}$

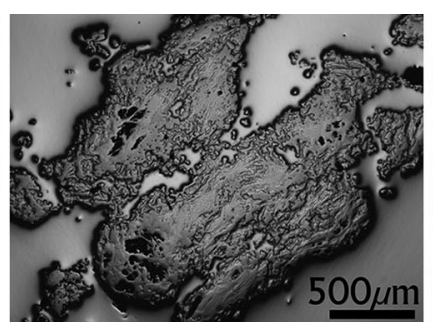

(c)

$10 \mu \mathrm{m} / \mathrm{s}$

$5 \mathrm{~mm}$

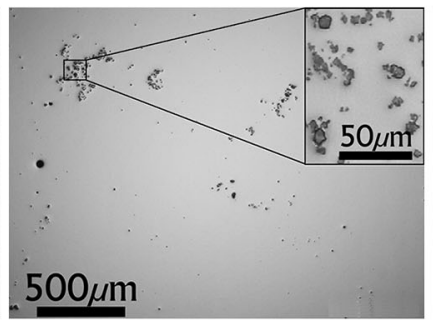

(g)

$>3000 \mu \mathrm{m} / \mathrm{s}$

$5 \mathrm{~mm}$

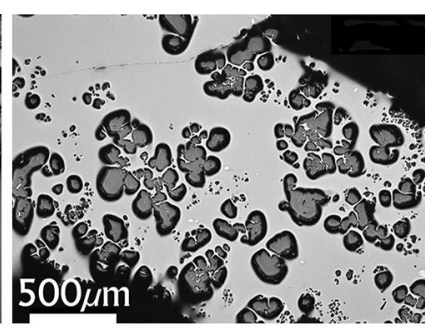

(d)

$10 \mu \mathrm{m} / \mathrm{s}$

$100 \mathrm{~mm}$ - top

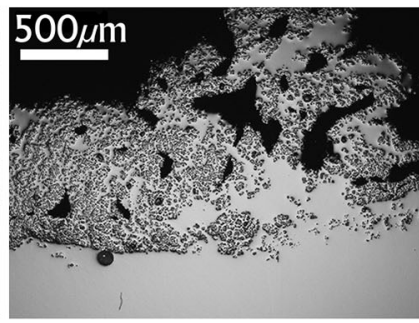

(h)

$>3000 \mu \mathrm{m} / \mathrm{s}$

$100 \mathrm{~mm}$ - top

Fig. 5-Microstructures observed in the optical microscope of samples extracted at different distances from the base of the ingots obtained in the solidification experiments at different mold velocities. Arrows indicate SiC particles.

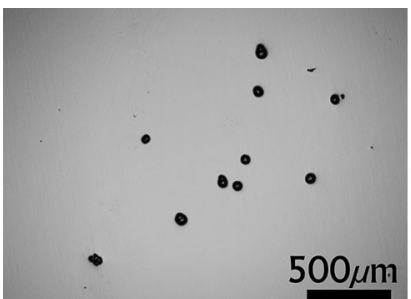

(a)

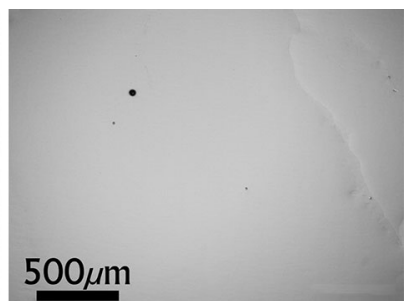

(b)

$75 \mathrm{~mm}$
Fig. 6-Microstructures observed in the optical microscope of samples extracted at different distances from the base of the ingots after $1 \mathrm{~h}$ of settling time.

concentration in this region (Figure 1). An accumulation of precipitated particles was confirmed at the ingot top for these experiments, as seen in Figures 5(b) and (d). Microanalysis by EDS (Energy Dispersive Spectrometry) of the particles indicated a composition of 41.7 at. pet of $\mathrm{C}$ and 58.4 at. pet of $\mathrm{Si}$, which is approximately the composition of $\mathrm{SiC}$. The micrograph of one particle, obtained in the scanning electron microscope (backscattered electron contrast), is in the insert of Figure 5(b). The bottom and middle part of these three ingots $(\mathrm{V}=5,10$, and $20 \mu \mathrm{m} / \mathrm{s})$ were free of particles, as seen in Figure 5(a) for the $5 \mu \mathrm{m} / \mathrm{s}$ pulling velocity. For $10 \mu \mathrm{m} / \mathrm{s}$, some isolated and unusually large particles were observed at the bottom of the ingot (Figure 5(c)), but these were not found in any other experiment, representing an anomalous behavior.

When the pulling velocity increases to 40 or $80 \mu \mathrm{m} / \mathrm{s}$, $\mathrm{SiC}$ particles exist throughout the ingot, as shown in Figures 5(e) and (f), indicating that the pushing of particles to the ingot top by the solid-liquid interface was less frequent. For these larger pulling velocities, a nonplanar solid-liquid interface is more likely, which is not as efficient as the planar interface to push particles, as explained by Stefanescu. ${ }^{[14]}$ Furthermore, as discussed in Section IV, the solidification front grew radially from the mold wall over most of the solidification time in these two experiments and, consequently, the front would be unable to push the particles to the top. At the ingot bottom, the particles are smaller and in less number than those in other regions, being consistent with an increase in carbon content from the ingot bottom to the top (Figure 1). For $40 \mu \mathrm{m} / \mathrm{s}$, the number and size of particles observed at the top was similar to those also found at the top for 5, 10, and $20 \mu \mathrm{m} / \mathrm{s}$, which is shown in Figures 5(b) and (d). In the case of $80 \mu \mathrm{m} / \mathrm{s}$, no significant accumulation of $\mathrm{SiC}$ particles is seen at the top, which is expected because a more uniform distribution of particles should occur as the pulling velocity increases. This distribution should eventually reduce to the uniform distribution observed for the largest pulling velocity $(>3000 \mu \mathrm{m} / \mathrm{s})$. 


\section{SETTLING TIME AND CARBON MACROSEGREGATION}

The macrosegregation of carbon in the two ingots obtained in the settling experiments is given in Figure 2, showing generally an increase in carbon content from the ingot top to the bottom. In both cases, the concentration profiles lie above the maximum carbon concentration limit suggested by the SEMI PV17-0611 for photovoltaic applications. An accumulation of $\mathrm{SiC}$ particles is observed at the bottom of the ingots (Figure 6(a)), which is consistent with the larger carbon concentration in this region. The accumulation is probably a result of the settling of $\mathrm{SiC}$ particles, with density $\sim 3200 \mathrm{~kg} / \mathrm{m}^{3}{ }^{[15]}$ down the silicon melt, of density $\sim 2560 \mathrm{~kg} / \mathrm{m}^{3} .{ }^{[16]}$ At $75 \mathrm{~mm}$ from the ingot base, a few SiC particles also exist, as shown in Figure 6(b).

The change in settling time $\left(t_{\mathrm{s}}\right)$ from 1 to 6 hours had no significant effect on the carbon macrosegregation, carbon concentration profile, or on the $\mathrm{SiC}$ particle distribution. During the solidification that occurred after the settling time, pushing of particles to the ingot top by the solid-liquid interface cannot have occurred, because the ingot macrostructures (Figure 4) display a mixture of columnar and equiaxed grains that probably grew in the radial direction as a result of the rapid heat extraction caused by rapid mold pulling. Therefore, the concentration profile along the ingot axial direction at the end of settling is unlikely to be affected by the subsequent solidification process.

In the insert of Figure 5(g), it is possible to see that the particle sizes are of the order of $10 \mu \mathrm{m}$ and would require approximately 1 hour to settle down from the ingot top to the bottom according to Stokes' law. Consequently, after 1 hour, settling would no longer affect the distribution of particles in the melt and, as observed experimentally, would not affect the carbon macrosegregation. The final $\mathrm{SiC}$ particle distribution and carbon concentration profiles must have been a result of a dynamic equilibrium between particle settling and particle transport by possible convection currents in the melt. These currents can exist as a result of radial temperature gradients and forces induced by the electromagnetic field of the induction coil of the furnace.

\section{CONCLUSIONS}

Experiments of directional solidification upward and of settling of $\mathrm{SiC}$ particles in the melt were carried out in a Bridgman furnace using electronic grade silicon (EGSi) intentionally contaminated with carbon. All ingots obtained in the solidification experiments have a macrosegregation of carbon to the ingot top. Approximately 80 pet of the volume of the ingots obtained with mold pulling velocities $\leq 40 \mu \mathrm{m} / \mathrm{s}$ have a carbon concentration below the maximum limit (43 ppm) defined by the SEMI PV17-0611 specification. The larger carbon concentration at the ingot top is a result of an accumulation of $\mathrm{SiC}$ particles. At these lower velocities, a large part of the macrostructure of the ingots consists of columnar grains aligned in the axial direction, which is consistent with a planar solid-liquid interface moving to the ingot top and pushing the $\mathrm{SiC}$ particles.

In the settling experiments, an increase of carbon concentration from the ingot top to the bottom is observed, as opposed to the directional solidification profiles, but the complete concentration profile lies above the maximum limit set by the SEMI PV17-0611 specification. This macrosegregation was confirmed to be the consequence of an accumulation of $\mathrm{SiC}$ particles at the ingot bottom as a result of settling. The intensity of the macrosegregation and the distribution of $\mathrm{SiC}$ particles along the ingots do not change for an increase in the settling time from 1 to 6 hours. Finally, in the conditions of the present work experiments, the directional solidification of silicon at mold pulling velocities lower than $40 \mu \mathrm{m} / \mathrm{s}$ is more effective to remove carbon from silicon than the settling of $\mathrm{SiC}$ particles during times up to 6 hours.

\section{ACKNOWLEDGMENTS}

The authors thank Conselho Nacional de Desenvolvimento Científico e Tecnológico (CNPq) (Grant 310923/2011-5), the Brazilian National Bank for Social and Economic Development (BNDES), and the Cia. Ferroligas Minas Gerais (MINASLIGAS) for financial support.

\section{REFERENCES}

1. H. Dalaker and M. Tangstad: Mater. Trans., 2009, vol. 50 (5), pp. $1152-56$.

2. G. Du, L. Zhou, P. Rossetto, and Y. Wan: Sol. Energy Mater. Sol. Cells, 2007, vol. 91 (18), pp. 1743-48.

3. A. Lotnyk, J. Bauer, O. Breitenstein, and H. Blumtritt: Sol. Energy Mater. Sol. Cells, 2008, vol. 92 (10), pp. 1236-40.

4. Semiconductor Equipment and Materials International: SEMI PV17-0611: Specification for Virgin Silicon Feedstock Materials for Photovoltaic Applications, 2011.

5. A.K. Soiland: Ph.D. Thesis, Norwegian University of Science and Technology, Trondheim, 2004.

6. D.M. Stefanescu, R.V. Phalnikar, H. Pang, S. Ahuja, and B.K. Dhindaw: ISIJ Int., 1995, vol. 35 (6), pp. 700-07.

7. A. Çiftja, T.A. Engh, M. Tangstad, A. Kvithyld, and E.J. Ovrelid: $J O M, 2009$, vol. 61 (11), pp. 56-61.

8. E. Ovrelid, B. Geerligs, A. Waernes, O. Raaness, I. Solheim, R. Jensen, K. Tange, S. Santeen, and B. Wiersma: Silicon Chem. Ind. VIII, [Conf.], Norwegian University of Technology, Trondheim, 2006, pp. 223-34.

9. J.D. Hunt: Mater. Sci. Eng., 1984, vol. 65 (1), pp. 75-83.

10. W. Kurz and D.J. Fisher: Fundamentals of Solidification, $3^{\text {rd }}$ ed., Trans. Tech. Publications, Aedermannsdorf, 1989.

11. T. Narushima, A. Yamashita, C. Ouchi, and Y. Iguchi: Mater. Trans., 2002, vol. 43 (8), pp. 2120-24.

12. M.A. Martorano, J.B.F. Neto, T.S. Oliveira, and T.O. Tsubaki: Metall. Mater. Trans. A, 2011, vol. 42A, pp. 1870-86.

13. M.A. Martorano, J.B.F. Neto, T.S. Oliveira, and T.O. Tsubaki: Mater Sci. Eng. B, 2011, vol. 76 (3), pp. 217-26.

14. D.M. Stefanescu: Science and Engineering of Casting Solidification, $2^{\text {nd }}$ ed., Springer, New York, 2009, pp. 283-301.

15. E.A. Brandes and G.B. Brook: Smithells Metals Reference Book, $7^{\text {th }}$ ed., Butterworth-Heinemann, Oxford, 1992, pp. 14.1-4.5.

16. K.C. Mills and L. Courtney: ISIJ Int., 2000, vol. 40, pp. S130-38. 